Life Science 10 (2) (2021)

Life Science

http://journal.unnes.ac.id/sju/index.php/LifeSci

\title{
Estimasi Kandungan Biomassa dan Simpanan Karbon Hutan Mangrove, Mangunharjo, Semarang
}

Wahyu Ika Apriliana ${ }^{\bowtie}$, Frida Purwanti, Nurul Latifah

Program Studi Manajemen Sumberdaya Perairan, Fakultas Perikanan dan Ilmu Kelautan Universitas Diponegoro, Indonesia

\begin{tabular}{l}
\hline Info Artikel \\
\hline Diterima: 1 September \\
2021 \\
Disetujui: 30 September \\
2021 \\
Dipublikasikan: 30 \\
November 2021 \\
\hline Keywords: \\
Carbon storage, $\mathrm{CO}_{2}$ \\
absorption, Mangrove forest \\
hutan mangrove; simpanan \\
karbon; serapan $\mathrm{CO}_{2}$ \\
\hline
\end{tabular}

\begin{abstract}
Mangrove forest is one of the coastal ecosystems that have a role for mitigating global warming in absorbing carbon from the atmosphere and storing it in the form of biomass. The aim of this research to know the content of biomass and carbon storage on the stems, carbon storage in sediments and estimation $\mathrm{CO}_{2}$ absorption of mangrove stems and sediment. This research was conducted in March 2021 in the Mangunharjo mangrove forest. The method used on this research is a survey method and using purposive samplimg to take samples in three research station by three plot transect. Analysis for the carbon storage in the stem using non-destructive method with allometric equations, while in the sediment using the LOI (Loss on Ignition) method. The result of biomass content and carbon storage in the mangrove stems 341,02 tons/ha and 156,87 tons/ha, carbon storage in the sediment 52,24 tons / ha and estimation $\mathrm{CO}_{2}$ absorption of mangrove stems and sediment based on carbon storage is 575,71 tons/ha, dan 191,73 tons/ha. Based on this research, the largest carbon storage and estimation $\mathrm{CO} 2$ absorption was on the stems of mangrove.
\end{abstract}

\begin{abstract}
Abstrak
Hutan mangrove merupakan salah satu ekositem pesisir yang berperan dalam mitigasi pemanasan global dengan menyerap karbon dari atmosfer dan menyimpannya dalam bentuk biomassa. Tujuan penelitian ini adalah mengetahui kandungan biomassa dan simpanan karbon pada tegakan, nilai simpanan karbon pada sedimen serta estimasi kemampuan tegakan dan sedimen dalam menyerap $\mathrm{CO}_{2}$. Penelitian dilakukan pada bulan Maret 2021 di hutan mangrove, Mangunharjo. Metode yang digunakan dalam penelitian ini adalah metode survey dan metode yang digunakan untuk mengambil sampel adalah purposive sampling yang dilakukan di 3 stasiun penelitian. Analisis untuk menghitung simpanan karbon di tegakan mangrove menggunakan metode non destructive dengan persaaman allometrik, sedangkan di sedimen menggunakan metode LOI (Loss on Ignition). Hasil nilai biomassa dan simpanan karbon pada tegakan mangrove yaitu 341,02 ton/ha, dan 156,87 ton/ha, simpanan karbon pada sedimen yaitu 52,24 ton/ha dan estimasi serapan $\mathrm{CO}_{2}$ pada tegakan dan sedimen berdasarkan simpanan karbon 575,71 ton/ha, dan 191,73 ton/ha. Berdasarkan hasil penelitian penyimpan karbon dan penyerap $\mathrm{CO}_{2}$ terbesar berada pada tegakan mangrove.
\end{abstract}

(C) 2021 Universitas Negeri Semarang

\footnotetext{
$\square$ Alamat korespondensi:

Program Studi Manajemen Sumberdaya Perairan, Universitas Diponegoro

E-mail: wahyuikaapriliana@gmail.com
}

p-ISSN 2252-6277

e-ISSN 2528-5009 


\section{PENDAHULUAN}

Pemanasan global merupakan masalah lingkungan yang ditandai dengan meningkatnya suhu di atas permukaan bumi. Pemanasan global dapat terjadi karena aktivitas manusia (antrophogenik) maupun aktivitas alami. Aktivitas manusia yang dapat menyebabkan pemanasan global yaitu semua aktivitas yang meningkatkan gas rumah kaca, salah satunya berasal dari pembakaran bahan bakar fosil yang melepaskan gas karbondioksida $\left(\mathrm{CO}_{2}\right)$ ke atmosfer (Lasmono dan Avia, 2014). Dampak dari pemanasan global sangat serius bagi lingkungan meliputi mencairnya es di Kutub Utara dan Selatan sehingga menyebabkan kenaikan muka air laut, perubahan iklim, dan lebih parahnya dapat mengakibatkan kepunahan bagi suatu flora dan fauna (Surtani, 2015).

Langkah yang dapat dilakukan untuk mengurangi $\mathrm{CO}_{2}$ di atmosfer adalah meningkatkan penyerapan $\mathrm{CO}_{2}$. Ekosistem pesisir dan lautan merupakan penyerap alami karbon (natural $\mathrm{CO}_{2} \operatorname{sink}$ ) terbesar di bumi. Kemampuan ekosistem pesisir dalam menyimpan karbon dari atmosfer lebih besar dibandingkan dengan penyerapan karbon yang dilakukan oleh hutan terrestrial (Muzani et al., 2020). Karbon yang disimpan oleh ekosistem pesisir disebut dengan blue carbon atau karbon biru. Menurut Sondak (2015), karbon biru merupakan salah satu jasa yang diberikan oleh ekosistem mangrove dan padang lamun untuk menanggulangi perubahan iklim global dengan menyerap dan menyimpan karbon yang berasal dari atmosfer dan samudera sehingga blue carbon kini diakui dalam menanggulangi perubahan iklim.

Hutan mangrove merupakan salah satu ekosistem pesisir yang memiliki kemampuan untuk menyerap dan menyimpan karbon dari atmosfer sehingga dapat berperan dalam upaya mitigasi pemanasan global. Menurut Azzahra et al. (2020), hutan mangrove memiliki kemampuan menyimpan karbon lebih dari tiga kali rata-rata dibandingkan dengan hutan tropis daratan. Fungsi optimal dalam menyerap karbon oleh mangrove mencapai 77,9\%, dimana karbon terserap akan disimpan dalam bentuk biomassa yang terdapat pada beberapa bagian pohon seperti batang, daun, dan sedimen.

Hutan mangrove mangunharjo terletak di RW V Tegalsari, Kelurahan Mangunharjo, Semarang. Menurut Tefarani et al. (2018), hutan mangrove Mangunharjo merupakan hutan buatan, dimana hutan tersebut mengalami kerusakan yang kemudian telah ditanami kembali oleh masyarakat sekitar dengan bantuan pemerintah serta LSM. Dalam penelitian terdahulu Suryono et al. (2018), menunjukan nilai biomassa above ground sebesar 187 ton/ha, simpanan karbonnya sebesar 86,11 ton/ha, dan nilai karbon organik sedimennya sebesar 359,24 ton/ha, akan tetapi pada penelitian ini tidak memiliki nilai seberapa besar tegakan dan sedimennya dalam menyerap $\mathrm{CO}_{2}$. Hutan mangrove Mangunharjo merupakan ekosistem penting dalam penyerapan karbon, oleh karena itu diperlukan penelitian untuk mengestimasi biomassa dan simpanan karbon pada hutan mangrove yang berguna untuk mengetahui kontribusi hutan mangrove dalam menyerap CO2 di atmosfer. Tujuan dari penelitian ini mengetahui nilai biomassa dan simpanan karbon pada tegakan mangrove, nilai simpanan karbon organik sedimen, dan kemampuan tegakan dan sedimen dalam menyerap $\mathrm{CO}_{2}$. 


\section{METODE}

Penelitian ini dilaksanakan pada bulan Maret 2021 di Hutan Mangrove Mangunharjo, Semarang (Gambar 1). Metode yang digunakan adalah metode survey, dimana melakukan pengamatan dan pengambilan sampel langsung di lapangan. Pengambilan data dengan menggunakan metode purposive sampling yang dilakukan di 3 stasiun penelitian di dekat laut, bekas tambak dan jauh dari laut dengan masing - masing stasiun terdiri dari 3 titik (lihat Gambar 1). Menurut Renta et al. (2016), metode purposive sampling merupakan metode pengambilan sampel yang dilakukan dengan mengambil data bukan didasarkan atas strata, random ataupun daerah, melainkan berdasarkan atas tujuan yang sudah ditetapkan.

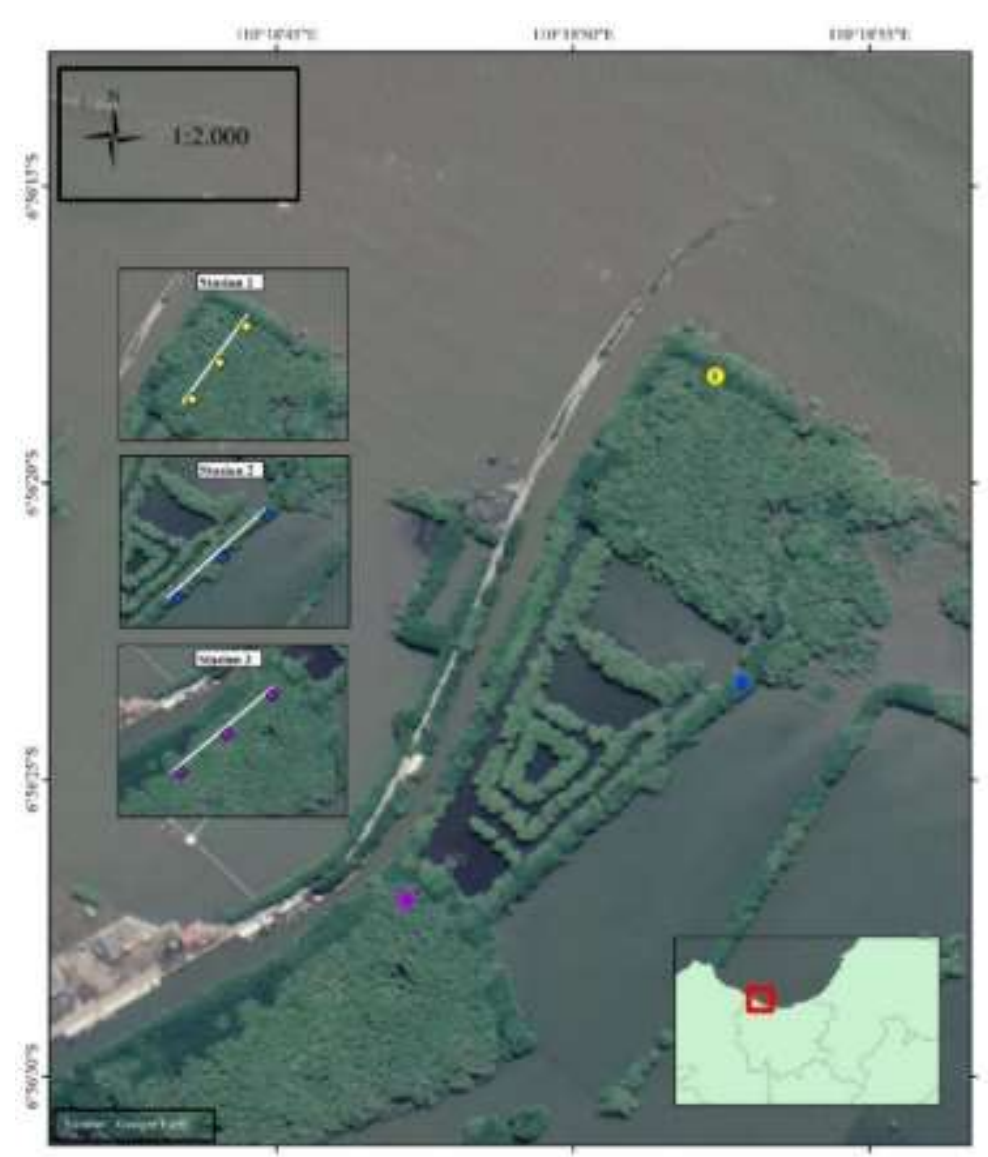

Gambar 1. Peta Lokasi Penelitian

\section{Pengambilan Data Diameter Pohon}

Pengukuran diameter pohon mangrove digunakan untuk menghitung biomassa dengan cara mengukur DBH (Diamater Breast High) pohon mangrove yakni setinggi dada atau kurang lebih 1,3 meter dari permukaan tanah dengan menggunakan meteran jahit (Cahyaningrum et al., 2014).

\section{Pengambilan Sampel Sedimen}

Pengambilan sampel sedimen menggunakan sediment correr yang dimodifikasi dengan menggunakan pipa PVC berdiameter $5 \mathrm{~cm}$ dengan tinggi $30 \mathrm{~cm}$, dimana sampel sedimen yang didapat kemudian disimpan kedalam plastic zipper. 


\section{Analisis Data}

Data DBH yang telah didapat dianalisis menggunakan persamaan allomatrik berdasarkan spesies mangrove yang telah diidentifikasi berdasarkan buku panduan pengenalan mangrove Indonesia. Persamaan allomatrik yang digunakan berdasarkan Dharmawan et al. (2010) serta Dharmawan dan Siregar (2008). Simpanan karbon pada tegakan dapat ditentukan menggunakan formula $46 \%$ dari biomassa merupakan karbon (Widyastuti et al., 2018). Analisis karbon organik sedimen dihitung menggunakan metode LOI dengan persamaan menghitung bahan organik berdasarkan Desnita et al. (2015). Kemampuan serapan $\mathrm{CO}_{2}$ pada tegakan dan sedimen mangrove dihitung berdasarkan persamaan Banuwa et al. (2019).

\section{HASIL DAN PEMBAHASAN}

Berdasarkan hasil identifikasi dan analisis struktur komposisi mangrove didapatkan 2 spesies mangrove sejati yang terdapat dilokasi penelitian yaitu Avicennia marina, dan Rhizophora mucronata.

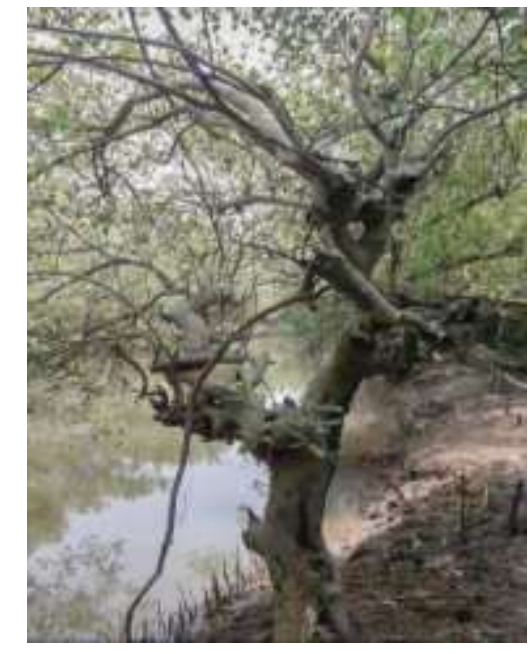

a

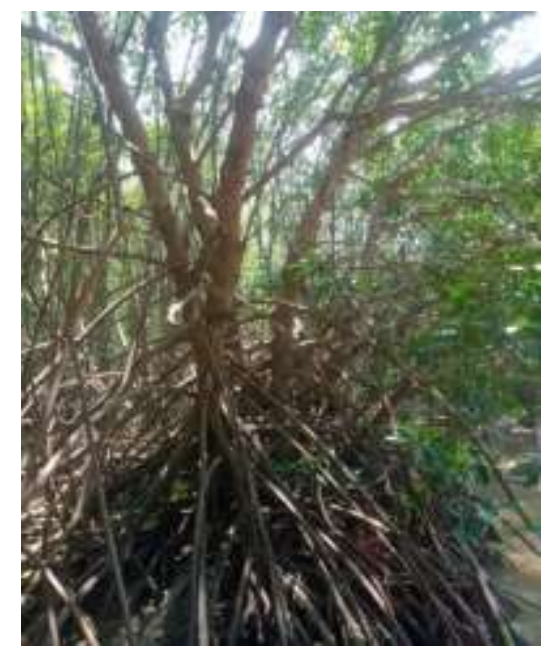

b

Gambar 2. A. marina (a), R. mucronata (b)

Spesies yang paling banyak ditemukan dari semua stasiun yaitu A. marina, hal ini dapat dilihat pada Tabel 1 yang menyajikan jenis mangrove yang ditemukan pada setiap titik di semua stasiun penelitian.

Tabel 1. Jenis Mangrove yang Ditemukan di Hutan Mangrove, Mangunharjo, Maret 2021

\begin{tabular}{|c|c|c|c|c|c|c|c|c|c|}
\hline \multirow{3}{*}{ Spesies } & \multicolumn{3}{|c|}{ Stasiun 1} & \multicolumn{3}{|c|}{ Stasiun 2} & \multicolumn{3}{|c|}{ Stasiun 3} \\
\hline & \multicolumn{9}{|c|}{ Pengulangan } \\
\hline & 1 & 2 & 3 & 1 & 2 & 3 & 1 & 2 & 3 \\
\hline Avicennia marina & + & + & + & + & + & + & + & + & + \\
\hline Rhizophora mucronata & + & + & + & + & + & + & + & - & - \\
\hline
\end{tabular}

Keterangan: $(+)=$ ditemukan; $(-)=$ tidak ditemukan 
Hasil penelitian biomassa dan karbon pada tegakan mangrove di hutan mangrove, Mangunharjo didapat dari tegakan pohon dengan $\mathrm{DBH}>5 \mathrm{~cm}$. Hasil perhitungan selengkapnya disajikan didalam Tabel 2.

Tabel 2. Biomassa, dan Karbon Tegakan per Spesies di Hutan Mangrove, Mangunharjo, Semarang, Maret 2021

\begin{tabular}{cccccc}
\hline Stasiun & Spesies & Ni & Kisaran DBH & Biomassa (ton/ha) & $\begin{array}{c}\text { Karbon } \\
\text { (ton/ha) }\end{array}$ \\
\hline \multirow{2}{*}{1} & A. marina & 34 & $7,01-28,34$ & 308,53 & 141,92 \\
& R. mucronata & 39 & $5,10-12,10$ & 81,80 & 37,63 \\
& Total & $\mathbf{7 3}$ & $\mathbf{5 , 1 0 - 2 8 , 3 4}$ & $\mathbf{3 9 0 , 3 3}$ & $\mathbf{1 7 9 , 5 5}$ \\
2 & A. marina & 13 & $7,32-38,32$ & 167,56 & 77,08 \\
& R. mucronata & 53 & $5,10-12,74$ & 136,51 & 62,79 \\
& Total & $\mathbf{6 6}$ & $\mathbf{5 , 1 0 - 3 8 , 3 2}$ & $\mathbf{3 0 4 , 0 6}$ & $\mathbf{1 3 9 , 8 7}$ \\
& A. marina & 58 & $5,41-20,06$ & 305,37 & 140,47 \\
& R. mucronata & 20 & $5,10-9,24$ & 23,29 & 10,71 \\
& Total & $\mathbf{7 8}$ & $\mathbf{5 , 1 0 - 2 0 , 0 6}$ & $\mathbf{3 2 8 , 6 6}$ & $\mathbf{1 5 1 , 1 8}$ \\
\hline
\end{tabular}

Tabel 2 menunjukan bahwa setiap stasiun penelitian memiliki nilai biomassa dan simpanan karbon yang berbeda. Nilai simpanan karbon akan meningkat seiring dengan meningkatnya nilai biomassa. Stasiun 1 memiliki nilai biomassa dan karbon tertinggi yaitu 390,33 ton/ha dan 179,55 ton/ha dengan total individu sebanyak 73. Nilai biomassa dan karbon terendah ditemukan pada stasiun 2 dimana nilai biomassanya sebesar 304,06 ton/ha dan nilai karbon 139,87 ton/ha, dengan total individu sebanyak 66. Faktor yang dapat menyebabkan tingginya nilai suatu biomassa dan simpanan karbon salah satunya adalah diameter pohon, hal ini sesuai dengan pernyataan Rahim (2018), yang menyatakan bahwa perbedaan nilai biomassa akan dipengaruhi oleh diameter pohonya, sehingga semakin besar diameter suatu pohon maka biomassa yang terkandung akan semakin besar pula.

Berdasarkan Tabel 2 juga diketahui bahwa mangrove jenis $A$. marina merupakan mangrove yang memiliki nilai biomassa tertinggi berturut turut dari stasiun 1 hingga 3 yaitu sebesar 308,53 ton/ha, 167,56 ton/ha dan 305,37 ton/ha, sedangkan nilai karbonnya bertutut turut dari stasiun 1 hingga 3 yaitu sebesar 141,92 ton/ha, 77,08 ton/ha dan 140,47 ton/ha. Nilai biomassa dan simpanan karbon mangrove $A$. marina lebih tinggi di seluruh lokasi penelitian dibandingkan dengan mangrove $R$. mucronata, hal ini disebabkan rata - rata diameter batang $A$. marina lebih besar dibandingkan dengan $R$. mucronata. Hal ini juga diperkuat oleh Manafe et al. (2016), dimana simpanan karbon tertinggi terdapat pada tegakan $A$. marina dibandingkan dengan $R$. mucronata. Perbedaan nilai biomassa dan simpanan karbon yang tersimpan disebabkan adanya perbedaan besarnya diameter tegakan pohon dimana semakin besar nilai diameter pohon maka berat biomassa pohon tersebut akan semakin besar. Besarnya berat biomassa akan mempengaruhi besarnya nilai simpanan karbon pada pohon tersebut.

Rata-rata nilai biomassa pada tegakan mangrove di hutan mangrove, Mangunharjo yaitu sebesar 341,02 ton/ha dengan nilai simpanan karbon yaitu sebesar 156,87 ton/ha pada jenis $A$. mariana dan $R$. 
mucronata serta jumlah tegakan pohonnya sebanyak 217. Biomassa dan simpanan karbon pada lokasi penelitian dikategorikan rendah apabila dibandingkan dengan penelitian Rahardani (2019), di Hutan Mangrove Nguling, Kabupaten Pasuruan dan Hutan Mangrove Tongas, Kabupaten Probolinggo yaitu sebesar 455,42 ton/ha dan 199,24 ton/ha dengan spesies A. alba, A. marina, R. apiculate dan R. mucronata serta jumlah tegakan pohonnya sebanyak 383. Hasil penelitian ini dikategorikan tinggi apabila dibandingkan dengan kawasan hutan trimulyo, Genuk, Semarang berdasarkan penelitian Rifandi dan Abdillah (2020), yang memiliki rata - rata biomassa sebesar 300,93 ton/ha dan simpanan karbon sebesar 141,437 ton/ha dengan jenis spesies $A$. marina dan $R$. mucronata serta jumlah tegakan pohonnya sebanyak 54.740 .

Tabel 3. Simpanan Karbon Sedimen Hutan Mangrove, Mangunharjo, Semarang, Maret 2021

\begin{tabular}{|c|c|c|c|c|c|}
\hline Stasiun & Plot & BD $\left(\mathrm{gr} / \mathrm{cm}^{3}\right)^{\text {a) }}$ & C-org (\%) & Kedalaman & $\operatorname{Karbon}(\operatorname{ton} / \mathrm{ha})^{\mathrm{c})}$ \\
\hline \multirow{3}{*}{1} & 1 & 0,67 & 2,476 & 30 & 50,11 \\
\hline & 2 & 0,77 & 2,180 & 30 & 50,27 \\
\hline & 3 & 0,72 & 2,676 & 30 & 57,71 \\
\hline \multicolumn{4}{|c|}{ Rata - Rata } & & 52,70 \\
\hline \multirow{3}{*}{2} & 1 & 0,65 & 2,158 & 30 & 41,80 \\
\hline & 2 & 0,62 & 2,439 & 30 & 45,43 \\
\hline & 3 & 0,66 & 2,314 & 30 & 45,59 \\
\hline \multicolumn{4}{|c|}{ Rata - Rata } & & 44,28 \\
\hline \multirow{3}{*}{3} & 1 & 0,75 & 2,723 & 30 & 61,33 \\
\hline & 2 & 0,72 & 2,832 & 30 & 61,49 \\
\hline & 3 & 0,72 & 2,600 & 30 & 56,45 \\
\hline \multicolumn{5}{|c|}{ Rata - Rata } & 59,75 \\
\hline
\end{tabular}

Keterangan $=$ data hasil perhitungan berat jenis tanah (a), data hasil analisis laboratorium karbon organik (b), data hasil perhitungan Bulk Density (BD) x \%C-org x Kedalaman (c)

Berdasarkan Tabel 2 rata - rata jenis sedimen yang terdapat di hutan mangrove, Mangunharjo yaitu lumpur. Stasiun 1 memiliki rata - rata berat jenis tanah yaitu sebesar $0,72 \mathrm{~g} / \mathrm{cm}^{3}$, stasiun 2 memiliki rata - rata berat jenis tanah sebesar $0,64 \mathrm{~g} / \mathrm{cm}^{3}$ dan stasiun memiliki rata - rata berat jenis tanah sebesar $0,73 \mathrm{~g} / \mathrm{cm}^{3}$ yang merupakan nilai tertinggi diantara ketiga stasiun penelitian. Berat jenis tanah merupakan salah satu faktor yang dapat mempengaruhi besar kecilnya nilai simpanan karbon sedimen, apabila semakin tinggi nilai berat jenis tanah (bulk density) maka kepadatan tanah akan semakin tinggi, sehingga kemampuan tanah tersebut dalam menyimpan karbon juga akan meningkat (Mahasani et al., 2015).

Nilai persentase C-organik pada sedimen mangrove di Hutan Mangrove, Mangunharjo berkirar 2,518 \% - 2,832\%. Stasiun 1 memiliki rata - rata presentase C-organik 2,44\%, kemudian stasiun 2 memiliki rata - rata presentase sebesar 2,304 \%, dan stasiun 3 memiliki rata - rata presentase sebesar 2,718. Hasil persentase C-organik pada penelitian memiliki nilai rendah apabila dibandingkan dengan 
penelitian Hakim et al. (2016) di Dukuh Tapak, Kelurahan Tugurejo, Kota Semarang yaitu rata - rata berkisar 4,4\%. Hasil persentase C-organik memiliki nilai tinggi apabila dibandingkan dengan penelitian Sulistyorini et al. (2020) di Teluk Kaba Taman Nasional Kutai yaitu rata - rata berkisar 2,70 \%. Besar kecilnya karbon organik tanah dapat dipengaruhi oleh serasah yang terdekomposisi di dalam tanah. Serasah merupakan penyusun utama bahan organik tumbuhan yang berasal dari batang, daun, ranting, dan buah yang jatuh di tanah. Bahan - bahan tersebut apabila jauh ke dalam tanah akan terdekomposisi oleh mikroorganisme sehingga menjadi unsur - unsur yang siap digunakan oleh tumbuhan. Salah satu proses didalam tanah sangat tergantung pada organisme tanah yaitu proses daur bahan organik (Nugraha et al., 2020). Faktor lain yang menyebabkan tinggi rendahnya nilai karbon organik tanah di hutan mangrove dapat dilihat dari besarnya ukuran diameter pohon, semakin lama usia mangrove maka semakin banyak bahan organik yang terurai (Suryono et al., 2018).

Berdasarkan hasil penelitian dapat diketahui bahwa stasiun 1 mampu menyimpan karbon dengan rata-rata sebesar 52,7 ton/ha, stasiun 2 sebesar 44,28 ton/ha dan stasiun 3 sebesar 59,75 ton/ha. Penentuan simpanan karbon organik sedimen dapat berdasarkan kandungan karbon organik tanah, berat jenis tanah dan kedalaman tanah. Menurut Donato et al. (2012), simpanan karbon organik di bawah permukaan mangrove dapat ditentukan dengan data kandungan karbon tanah, berat jenis tanah (bulk density), dan kedalaman tanah, serta bagaimana ketiga faktor yang telah disebutkan bervariasi secara spasial.

Hasil simpanan karbon sedimen pada penelitian ini dikategorikan rendah dibandingkan dengan simpanan karbon pada tegakan yang diakibatkan salah satunya oleh faktor kedalaman pengambilan sampel. Kandungan bahan organik dalam sedimen yang tinggi memiliki rata - rata kedalaman antara 0,5 m sampai dengan lebih dari $3 \mathrm{~m}$ (Donato et al., 2012). Hal ini diperkuat oleh Verisandria et al. (2018), yang menyatakan bahwa nilai simpanan karbon tertinggi didapatkan pada kedalaman $60-100 \mathrm{~cm}$. Hasil yang diperoleh menunjukan semakin dalam pengambilan sampel maka kandungan karbon organik sedimen semakin meningkat.

Rata - rata simpanan karbon sedimen di Hutan Mangrove Mangunharjo memiliki nilai sebesar 52,24 ton/ha. Kemampuan menyimpan karbon organik sedimen pada penelitian ini dikategorikan lebih tinggi dibandingkan dengan penelitian Ariani et al. (2016) di area hutan mangrove PT. Indocement Tunggal Prakasa, TBK P 12 Tarjun yaitu sebesar 26,03 ton/ha. Namun, kemampuan menyimpan karbon organik sedimen pada penelitian ini dikatakan rendah jika dibandingkan dengan penelitian Ayu et al. (2020) di ekosistem mangrove, Kelurahan Songka, Kota Palopo yaitu sebesar 163,08 ton/ha. Faktor yang menyebabkan rendahnya nilai karbon didalam sedimen salah satunya adalah kedalaman tanah. 
Tabel 4. Kemampuan menyerap $\mathrm{CO}_{2}$ pada Tegakan Mangrove Mangunharjo, Semarang, Maret 2021

\begin{tabular}{|c|c|c|c|}
\hline Stasiun & Spesies & Karbon (ton/ha) & $\mathrm{WCO}_{2}$ (ton/ha) \\
\hline \multirow{3}{*}{1} & A. marina & 141,92 & 520,86 \\
\hline & R. mucronata & 37,63 & 138,10 \\
\hline & Total & 179,55 & 658,96 \\
\hline \multirow{3}{*}{2} & A. marina & 77,08 & 282,87 \\
\hline & R. mucronata & 62,79 & 230,45 \\
\hline & Total & 139,87 & 513,32 \\
\hline \multirow{3}{*}{3} & A. marina & 140,47 & 515,53 \\
\hline & R. mucronata & 10,71 & 39,31 \\
\hline & Total & 151,18 & 554,84 \\
\hline \multicolumn{2}{|c|}{ Rata - Rata } & 156,87 & 575,71 \\
\hline
\end{tabular}

Tabel 5. Kemampuan menyerap $\mathrm{CO}_{2}$ pada Sedimen Mangrove Mangunharjo, Semarang, Maret 2021

\begin{tabular}{|c|c|c|c|}
\hline Stasiun & Plot & Karbon (ton/ $\left.\mathbf{H a}^{2}\right)$ & $\mathrm{WCO}_{2}$ (ton/ha) \\
\hline \multirow{3}{*}{1} & 1 & 50,11 & 183,91 \\
\hline & 2 & 50,27 & 184,49 \\
\hline & 3 & 57,71 & 211,8 \\
\hline \multicolumn{2}{|c|}{ Rata - Rata } & 52,70 & 193,4 \\
\hline \multirow{3}{*}{2} & 1 & 41,8 & 153,41 \\
\hline & 2 & 45,43 & 166,74 \\
\hline & 3 & 45,59 & 167,32 \\
\hline \multicolumn{2}{|c|}{ Rata - Rata } & 44,28 & 162,49 \\
\hline \multirow{3}{*}{3} & 1 & 61,33 & 225,08 \\
\hline & 2 & 61,49 & 225,65 \\
\hline & 3 & 56,45 & 207,17 \\
\hline \multicolumn{2}{|c|}{ Rata - Rata } & 59,75 & 219,3 \\
\hline \multicolumn{2}{|c|}{ Rata-Rata Total } & 52,24 & 191,73 \\
\hline
\end{tabular}

Tabel 5 menunjukan bahwa kemampuan tegakan hutan mangrove dalam menyerap $\mathrm{CO}_{2}$, di Mangunharjo pada stasiun 1 memiliki nilai sebesar 658,96 ton/ha setara dengan simpanan karbon 175,55 ton/ha yang merupakan nilai tertinggi di ketiga stasiun penelitian, stasiun 2 memiliki nilai serapan $\mathrm{CO}_{2}$ sebesar 513,32 setara dengan simpanan karbon 139,87 ton/ha yang merupakan nilai terendah di ketiga stasiun penelitian, dan stasiun 3 memiliki nilai sebesar 554,84 ton/ha setara dengan simpanan karbon 151,18 ton/ha. Besar kecilnya nilai kemampuan menyerap $\mathrm{CO}_{2}$ dapat ditentukan berdasarkan nilai biomassa dan simpanan karbonnya. Hal ini diperkuat oleh Heriyanto dan Subiandono (2016), yang menyatakan bahwa penyerapan $\mathrm{CO}_{2}$ berhubungan dengan nilai biomassa dan simpanan karbonnya. 
Suatu kawasan dapat memperoleh nilai biomassanya berdasarkan hasil pengukuran $\mathrm{DBH}$, berat jenis, dan kepadatan setiap jenis pohon, serta kesuburan tanah.

Rata - rata kemampuan penyerapan $\mathrm{CO}_{2}$ pada tegakan $A$. marina memiliki nilai sebesar 439,75 ton/ha yang setara dengan simpanan karbon 119,82 ton/ha, sedangkan pada tegakan $R$. mucronata memiliki nilai serapan $\mathrm{CO}_{2}$ sebesar 135,96 ton/ha yang setara dengan simpanan karbon 37,04 ton/ha. Tingginya nilai penyarapan $\mathrm{CO}_{2}$ A. marina salah satunya dipengaruhi oleh besarnya nilai diameter pohon, semakin besar nilai diameter makan nilai serapan $\mathrm{CO}_{2}$ nya juga akan semakin meningkat. Seiring dengan meningkatnya nilai diameter pada tegakan pohon maka akan menghasilkan nilai biomassa dan simpanan karbon yang tinggi pula. Setiap penambahan nilai biomassa akan diikuti oleh penambahan nilai simpanan karbon dan sekuestrasi karbon karena terjadi penyerapan $\mathrm{CO}_{2}$ dari atmosfer melalui proses fotosintesis yang menghasilkan biomassa untuk dialokasikan ke organ tumbuhan seperti daun, ranting, batang dan akar (Nedhisa dan Tjahjaningrum, 2019).

Berdasarkan hasil yang telah diperoleh menunjukan bahwa serapan $\mathrm{CO}_{2}$ pada sedimen hutan mangrove, Mangunharjo di stasiun 1 memiliki rata - rata sebesar 193,40 ton/ha yang setara dengan simpanan karbon 52,70 ton/ha, stasiun 2 memiliki rata - rata serapan $\mathrm{CO}_{2}$ sebesar 162,49 ton/ha yang setara dengan simpanan karbon 44,28 ton/ha merupakan nilai terendah di ketiga stasiun, dan stasiun 3 merupakan kawasan dengan penyerapan CO2 tertinggi di dalam sedimen dengan nilai 219,30 ton/ha yang setara dengan 59,75 ton/ha simpanan karbon.

Kemampuan tegakan mangrove di hutan mangrove, Mangunharjo dalam menyerap $\mathrm{CO}_{2}$ di atmosfer memiliki nilai sebesar 575,71 ton/ha. Nilai ini lebih tinggi dibandingkan dengan penelitian Hidayah et al. (2020), di Desa Kelapa Pati, Kabupaten Bengkalis yaitu sebesar 195,13 ton/ha. Namun, keampuan menyerap $\mathrm{CO}_{2}$ tegakan pada penelitian ini juga dikatakan rendah apabila dibandingkan dengan penelitian milik Azzahra et al. (2020), di Desa Bedono, Demak, Jawa Tengah yaitu sebesar 697,607 ton/ha. Nilai rata - rata kemampuan menyerap $\mathrm{CO}_{2}$ di sedimen mangrove, hutan mangrove Mangunharjo sebesar 191,73 ton/ha. Hasil ini lebih tinggi dibandingan dengan penelitian Nugraha et al. (2020), di Desa Kawlingi, Kabupaten Brebes sebesar 34,75 ton/ha. Penelitian ini juga dikatakan rendah apabila dibandingkan dengan penelitian Susilowati et al. (2020), di hutan mangrove Desa Tambak Bulusan, Demak, Jawa Tengah yaitu sebesar 211, 89 ton/ha.

\section{SIMPULAN}

Nilai biomassa di tegakan hutan mangrove, Mangunharjo sebesar 341,02 ton/ha, sedangkan nilai simpanan karbon pada tegakannya yaitu sebesar 156,87 ton/ha. Nilai simpanan karbon sedimen mangrove yang diperoleh sebesar 52,24 ton/ha. Kemampuan menyerap $\mathrm{CO}_{2}$ pada tegakan mangrove lebih tinggi dibandingkan dengan sedimen yaitu 575,71 ton/ha, sedangkan kemampuan menyerap $\mathrm{CO}_{2}$ pada sedimen mangrove diperoleh sebesar 191,73 ton/ha. 


\section{UCAPAN TERIMA KASIH}

Ucapan terimakasih kepada Ketua RW V Tanggul Sari, Mangunharjo yang telah memberikan izin untuk melakukan penelitian dan seluruh pihak yang telah berkontribusi dalam penelitian ini sehingga penelitian ini dapat terlaksana dengan baik.

\section{DAFTAR PUSTAKA}

Ariani, E., M. Ruslan, A. Kurnain \& Kissinger. (2016). Analisis Potensi Simpanan Karbon Hutan Mangrove di Area PT. Indocement Tunggal Prakarsa, Tbk P 12 Tarjun. Jurnal EnviroScienteae, 12(3), 312-329.

Ayu, S. D., A. Rosdayati, \& N. N. Nadjib. (2020). Simpanan Karbon Tanah pada Ekosistem Mangrove Kelurahan Songka Kota Palopo. Jurnal Tabaro, 4(2), 484-489.

Azzahra, F. S., Suryanti, \& S. Febrianto. (2020). Estimasi Serapan Karbon pada Hutan Mangrove Desa Bedono, Demak, Jawa Tengah. Journal of Fisheries and Marine Research, 4(2), 308-315.

Banuwa, I. S., R. Afriliyanti, M. Utomo, S. Yusnaini, M. Riniarti, P. Sanjaya, E. Suroso \& W. Hidayat. (2019). Short Communication: Estimation of The Above- and Below-Ground Carbon Stocks in University of Lampung, Indonesia. Jurnal Biodiversitas, 20(3), 676-681.

Cahyaningrum, S. T., A. Hartoko, dan Suryanti. (2014). Biomassa Karbon Mangrove pada Kawasan Mangrove Pulau Kemujan Taman Nasional Karimunjawa. Journal of Management of Aquatic Resources, 3(3), 34-42. http://ejournal-s1.undip.ac.id/index.php/maquares

Desnita, D., Y. Widodo \& S. Tantalo YS. (2015). Pengaruh Penambahan Tepung Gaplek dengan Level yang Berbeda terhadap Kadar Bahan Kering dan Kadar Bahan Organik Silase Limbah Sayuran. Jurnal Ilmiah Peternakan Terpadu, 3(3), 140-144.

Dharmawan, I. W. S. (2010). Pendugaan Biomasa Karbon di atas Tanah pada Tegakan Rhizophora Mucronata di Ciasem, Purwakarta. Jurnal Ilmu Pertanian Indonesia, 15(1), 50-56.

Dharmawan, I. W. S., dan C. A. Siregar. (2008). Karbon Tanah dan Pendugaan Karbon Tegakan Avicennia Marina (Forsk.) Vierh. di Ciasem, Purwakarta (Soil Carbon and Carbon Estimation of Avicennia Marina (Forsk.) Vierh. Stand at Ciasem, Purwakarta). Jurnal Penelitian Hutan dan Konservasi Alam, 5(4), 317-328.

Donato, D. C., J. B. Kauffman, D. Murdiyarso, S. Kurnianto, M. Stidham, \& M. Kanninen. (2012). Mangrove adalah salah satu hutan terkaya karbon di kawasan tropis, Brief Cifor, 12, 1-10.

Hakim, M. A., N. K. T. Martuti \& A. Irsadi. (2016). Estimasi Stok Karbon Mangrove di Dukuh Tapak Kelurahan Tugurejo Kota Semarang. Life Science, 5(2), 87-94.

Heriyanto, N. M., \& E. Subiandono. (2016). Peran Biomasa Mangrove dalam Menyimpan Karbon di Kubu Raya, Kalimantan Barat. Jurnal Analisis Kebijakan, 13(1) : 1-12

Lasmono, F., \& L. Q. Avia. (2014). Bagaimana Kontribusi Aktivitas Manusia Terhadap Perubahan Iklim. Media Dirgantara, 9(2).

Mahasani, I. G. A. I., N. Widagti, \& I. W. G. A. Karang. (2015). Estimasi Presentase Karbon Organik di Hutan Mangrove Bekas Tambak, Perancak, Jembrana Bali. Journal of Marine and Aquatic Science, $1,14-18$.

Manafe, G., M. R. Kaho, \& F. Risamasu. (2016). Estimasi Biomassa Permukaan dan Stok Karbon pada Tegakan Pohon Avicennia marina dan Rhizophora mucronata di Perairan Pesisir Oebelo Kabupaten Kupang. Bumi Lestari Journal Of Environment, 16(2), 163-173.

Muzani, M., A. P. A. Purwindiyanto, E. M. E, Meylani, R. A. R. Andika, \& R. N. R. Nurfadilah. (2020). Potensi Taman Mangrove Pulau Pramuka Sebagai Destinasi Edutourism. Jurnal Hutan Tropis, 8(3), 348-356.

Nedhisa, P. I. \& I. T. Tjahjaningrum. (2019). Estimasi Biomassa, Stok Karbon dan Sekuestrasi Karbon Mangrove pada Rhizophora mucronata di Wonorejo Surabaya dengan Persamaan Allometrik. Jurnal Sains dan Seni ITS, 8(2), 61-65 
Nugraha, F. W., R. Pribadi, dan A. Wirasatriya. (2020). Kajian Perubahan Luasan untuk Prediksi Simpanan Karbon Ekosistem Mangrove di Desa Kaliwlingi, Kabupaten Brebes. Buletin Oseanografi Marina, 9(2), 104-116.

Rahardani, A. M. (2019). Estimasi Serapan Karbon pada Vegetasi Mangrove di Hutan Mangrove Nguling Kabupaten Pasuruan dan di Hutan Mangrove Tongas Kabupaten Probolinggo Provinsi Jawa Timur. [Skripsi] Universitas Brawijaya.

Rahim, S., Baderan, D. K., \& Hamidun, M. S. (2018). Keanekaragam Spesies, Biomassa dan Stok Karbon pada Hutan Mangrove Torosiaje Kabupaten Pohuwato-Provinsi Gorontalo. Pro-Life, 5(3), 650-665

Renta, P. P., R. Pribadi, M. Zainuri, \& M. A. F. Utami. (2016). Struktur komunitas mangrove di Desa Mojo Kabupaten Pemalang Jawa Tengah. Jurnal Enggano, 1(2), 1-10.

Rifandi, R. A., \& R. F. Abdillah. (2020). Estimasi Stok Karbon Dan Serapan Karbon Pada Tegakan Pohon Mangrove Di Hutan Mangrove Trimulyo, Genuk, Semarang. Envoist Journal, 1 (2), 11-18.

Sondak, C. F. A. (2015). Estimasi Potensi Penyerapan Karbon Biru (Blue Carbon) oleh Hutan Mangrove Sulawesi Utara. Jurnal of Asean Studies on Maritime Issues, 1(1), 24-29. https://ejournal.unsrat.ac.id/index.php/jasmi/article/view/12501

Sulistyorini, I. S., M. Edwin dan Imanudin. (2020). Estimasi Stok Karbon Tanah Organik pada Mangrove di Teluk Kaba dan Muara Teluk Pandan Taman Nasional Kutai. Jurnal AGRIFOR, 19(2), 293-302.

Surtani, S. (2015). Efek Rumah Kaca Dalam Perspektif Global (Pemanasan Global Akibat Efek Rumah Kaca). Jurnal Geografi, 4(1), 49-55.

Suryono, S., N. Soenardjo, E. Wibowo, R. Ario, \& E. F. Rozy. (2018). Estimasi Kandungan Biomassa dan Karbon di Hutan Mangrove Perancak Kabupaten Jembrana, Provinsi Bali. Buletin Oseanografi Marina, 7(1), 1-8.

Susilowati, M. W., P. W. Purnomo, \& A. Solichin. (2020). Estimasi Serapan $\mathrm{CO}_{2}$ Berdasarkan Simpanan Karbon Pada Hutan Mangrove Desa Tambakbulusan Demak Jawa Tengah. Jurnal Pesisir Laut. 4(2), 86-94.

Tefarani, R., N. K. T. Martuti, \& S. Ngabekti. (2019). Keanekaragaman spesies mangrove dan zonasi di wilayah Kelurahan Mangunharjo Kecamatan Tugu Kota Semarang. Life Science, 8(1), 41-53. https://doi.org/10.15294/lifesci.v8i1.29989

Verisandria, R. J., J. N.W. Schaduw, C. F. A. Sondak, M. Ompi, A. Rumengan \& J. Rangan. (2018). Estimasi Potensi Karbon pada Sedimen Ekosistem Mangrove di Pesisir Taman Nasional Bunaken Bagian Utara. Jurnal Pesisir dan Laut Tropis, 1(1), 81-97.

Widyastuti, A., E. Yani, E. K. Nasution dan Rochmatino. (2018). Diversity of Mangrove Vegetation and Carbon Sink Estimation of Segara Anakan Mangrove Forest, Cilacap, Central Java, Indonesia. Jurnal Biodiversitas, 19(1), 246-252. 